\title{
Early Warning Mechanism for Mitigating Herders and Farmers Conflict in Benue States, Nigeria
}

\author{
Efe Ijoyah \\ Institute for Peace and Conflict Resolution, Abuja Nigeria, PMB 349, Plot 496, Abogo Largema Street, CBD \\ Garki, Abuja- Nigeria
}

\begin{abstract}
Early warning has emerged as a contemporary instrument relevant for conflict management, resolution and peace building. In Nigeria, violent conflict related to the herders-farmers conflicts has resulted in massive loss of lives, destruction of property, internal displacement of person, among others. The conflict has progressively become prevalent and protracted. Extant literature has investigated the dynamics, conflict management strategies deployed, as well as the challenges of managing the herders and farmers conflict in Nigeria. However, this study examined the prospects and potentials of early warning mechanisms as instrument for mitigating the herders-farmers conflicts in Nigeria, using Benue and Nasarawa states as case studies. Homer Dixon's Eco-violence Theory served as the study's theoretical framework. The study adopts primary and secondary methods of data collection. Findings revealed that the contemporary causes of the conflict included climate change, demographic increase, influx of foreign herders. The effects of the conflict are: emergence of militias/vigilante groups, upsurge in internal displacement of persons, breakdown of inter-group relations and distortion in the agricultural sector. Furthermore, the study revealed that establishment of Early Warning Centers at the grass root, deployment of early response mechanism among others are strategies through which early warning mechanism can be used to mitigate the herders and farmers conflict. The study recommends enactment of grazing laws that will incorporate and protect the interest of herders and farmers.
\end{abstract}

Keywords: Early Warning Mechanism, Conflict Management, Resolution, Benue, Nasarawa, plateau Herders \& Farmers

DOI: $10.7176 / \mathrm{JAAS} / 69-03$

Publication date:October $31^{\text {st }} 2020$

\section{Introduction}

In 1992, early warning was introduced as mechanism for conflict prevention and management in the United Nations after the Secretary-General Boutros Boutros Ghali's report, 'An Agenda for Peace', highlighted the link between humanitarian actions and the peace process. In the report, Boutros Ghali outlined the 'valuable work' of the early warning system on environmental threats, the risk of nuclear accidents, natural disasters, mass movements of populations, the threat of famine and the spread of disease. He stressed that 'there is a need to strengthen arrangements in such a manner that information from these sources can be synthesized with political indicators to assess whether a threat to peace exists and to analyze what action might be taken by the United Nation to alleviate it (Tiruneh, 2010 cited in Amao, et al, 2014). Consequently, within the past two decades, the importance of proactive strategies to conflicts prevention and management rather than reactive measures have gained ground among conflict prevention and management stakeholders globally. Nwaneri and Uwakwe (2017:131) argued that it is becoming obvious to governments, organizations and individuals that prevention of violent conflicts through early warning is more effective in terms of cost and saving lives.

Conflict and violence are phenomena in every society; indeed, there have been a global upsurge in conflict and violence resulting in loss of lives, destruction of property and internal displacement of persons. In fact, extant literature has showcased that conflict is an integral aspect of human life. Scholars such as Karl Marx, (1818-1832) and Frederic Engels, (1820-1895) argued that the history of all existing societies is the history of class struggles which could be evolutionary or revolutionary, thus lending credence to the existence of conflicts, in every societies. Domenici and Littlejohn (2001), asserted that conflict actually depends on expressed struggle, interdependence, perceived incompatibility of goals, scarce rewards and interference. Anioke (2002) defined conflict as a difference or disagreement of opinions, ideals or goals between parties, individuals or groups. Bloisi (2007) defines it as a disagreement between two or more parties who perceive that they have incompatible goals and needs. Henry (2009) also noted that a conflict can occur when interests, goals or values of different individuals or groups become incompatible with one other. Hocker and Wilmont (2011) defined it as a "felt struggle between two or more interdependent individuals or groups over perceived and incompatible differences in beliefs, values, and goals, or over differences in desires for esteem, control and connectedness". Hocker and Wilmont (2011) definition, points out several aspects of conflict which needs attention, such as it being a sensed struggle between two or more individuals/groups and secondly, arising as a result of incompatible differences. Indeed, the definition aptly reflect the herder-farmer conflict phenomenon in Benue and Nasarawa states, Nigeria. Herders and farmers are interdependent i.e both need each other. Similarly, the conflict is as a result of the struggle for resource (land 
ownership and usage)

In Nigeria, herders-farmers conflict is significantly rampant in Benue and Nasarawa states. The two states are located in the North- Central geo-political zone of the country. Historically, Benue state was created on February $3^{\text {rd }}, 1976$ from the former Benue -Plateau state, with a population of over 4 million people (Census, 2006). The state is made up of various ethnic groups including Tiv, Idoma, Igede, Etulo Abakpa, Nyifon and Akweya. The Tiv are the dominant ethnic group occupying 14 local government areas and are predominantly farmers. Similarly, Nasarawa state came into existence on the $1^{\text {st }}$ of October, 1996. It was created out of former Plateau state. The state has ten local government areas and occupies a total land area of 27,137.8 sq.km. It shares borders on the south with Benue state, on the East with Plateau and Taraba states, on the North with Kaduna state and on the west by the Federal Capital Territory- Abuja. They people are predominantly farmers.

Scholars (Abdulbaqi \& Ariemu, 2017, Bagu \& Smith, 2017) have argued that violence related to the herdersfarmers conflicts have resulted in massive loss of lives, destruction of property, internal displacement of person, among others. Ilo, Jonathan-Ichaver \& Adamolekun (2019) described the herder-farmers conflict in Nigeria as "one of the world's deadliest conflicts". Sahara Reporters (2019) submitted that between January-March, of the same year, 179 lives were lost to the conflict. Similarly, Chiluwa and Chiluwa (2020) noted that over 10,000 lives have been lost as a result of the conflict in the last ten years and almost 4,000 of them in the last two years alone. Consequently, this study examined the prospects and potentials of early warning mechanisms as instrument for mitigating the herders-farmers conflicts in Nigeria, using Benue and Nasarawa states as case studies.

\subsection{Aims and Objectives 2}

The aim of this paper is to undertake an examination of early warning mechanisms as instruments for mitigating the herders-farmers conflicts in Nigeria using Benue and Nasarawa states as case studies. The specific objectives are:

1. Identify the contemporary factors that have sustained the herders-farmers conflicts in Benue and Nasarawa states, Nigeria

2. Examine the effects of the herders-farmers conflicts in Benue and Nasarawa states, Nigeria

3. Explore how early warning mechanisms can be deployed and utilized towards mitigating the herdersfarmers conflicts in Benue and Nasarawa states, Nigeria

\subsubsection{Methodology}

This study applies a qualitative discourse analysis method to examine the conflict mitigating prospects and potentials of early warning mechanisms within the context of herders-farmers conflict in Benue and Nasarawa states, Nigeria. Both primarily and secondary research paradigms were employed in sourcing for data. Primary data emerged from interviews while secondary data was retrieved from newspapers, journals articles and books. Purposive sampling was used to select 40 (20 each in Benue and Nasarawa states) interview respondents including representatives of herders, farmers, youths, women and state government officials.

The data collection process was guided by the research ethics of voluntary participation, anonymity, and respect. First, the process of recruiting respondents was determined by respondents' willingness to participate in the study. Second, respondents were assured of anonymity and confidentiality of their personal information. Third, the researcher ensured that no responses were identified with the respondents. Confidentiality and anonymity of responses helped to reduce the incidence of bias.

\subsubsection{Data analysis}

The recordings of the study's interview sessions were transcribed using Express Scribe Transcription Software) and anonymized to protect the identity of the respondents. This was followed by the coding and reading of the data into Nvivo, qualitative research analytical software. Findings were analyzed in thematically. After complete transcription and analysis, the interview recordings were securely destroyed. The study's three specific objectives were analyzed, and they include: (i) identify the contemporary factors that have sustained the herders-farmers conflicts in Benue and Nasarawa states, Nigeria; (ii) examine the effects of the herders-farmers conflicts in Benue and Nasarawa states, Nigeria; and (iii) explore how early warning mechanisms can be deployed and utilized towards mitigating the herders-farmers conflicts in Benue and Nasarawa states, Nigeria. This study should be generalized with caution given the limited number of respondents $(n=40)$ that were involved. However, this limitation does not invalidate the findings of the study.

\subsection{Conflicts in Nigeria}

There is no universal agreement regarding the definition of conflict. It has many definitions and conceptions, depending on the issues being addressed (Yorid and Pakia, 2013). Chukwuemeka, Ugwu, Okey, and Igwegbe (2012) confirmed this lack of consensus definition among scholars and writers. However, most writers agree that conflict is an inevitable phenomenon in any organization (Akomolafe, 2002; Fatile and Adejuwon, 2011). According to Borisoff and Victor (1998), it is difficult to define conflict or come to a consensus with regard to its definition. Suppiah and Rose (2006) consented to this by stating that there is no comprehensive definition of 
conflict as the definition varies depending on the discipline to which it is applied and the perspective from which it is viewed. However, they went further to assert that conflict is a natural consequence of interaction with people and therefore inevitable. To buttress this argument, Ejiogun (1990) had prior to this time, stated that conflict is bound to happen regularly in all human interactions and organizational behavior. Conflict is derived from the Latin word "conflictus" which means strike together. Domenici and Littlejohn (2001) on the other hand, asserted that conflict actually depends on expressed struggle, interdependence, perceived incompatibility of goals, scarce rewards and interference. While Hocker and Wilmont (2011) defined it as a "felt struggle between two or more interdependent individuals over perceived and incompatible differences in beliefs, values, and goals, or over differences in desires for esteem, control and connectedness". Hocker and Wilmont (2011) definition, points out several aspects of conflict which needs attention, such as being a sensed struggle between two or more individuals and secondly, arising as a result of incompatible differences. Fatile and Adejuwon (2011) see conflict as what happens when two or more persons have opposing ideals over how resources that pertains to their development are to be shared. Nahawandi, Denhardt, Denhardt, and Aristigueta (2015) define conflict as a process in which people have divergent opinions over important issues that affect them thereby leading to serious disagreement. Thus, Domenici and Littlejohn (2001), Henry (2009), Fatile and Adejuwon (2011), and Hocker and Wilmont (2011) viewed conflict from the goal perspective, as a struggle with opposing forces having divergent interests coming together. Based on the various definitions of conflict, Chukwuemeka et al, (2012) stated that conflict either manifests itself overtly or covertly, thereby enabling people to feel its existence. Arising from this, conflict can manifest itself within an individual and this is known as intra-personal conflict; between two or more groups, interpersonal conflict; between or among groups of people, units or departments, inter-group or inter-unit conflict and lastly, between or among different organizations or nations and this is known as inter-organizational or international conflict. Rahim (2002) stated that conflict can occur when the following happens: a party is required to participate in activities that contrast with such a person's interest; a party exhibits a certain social tendency which infringes on or is incompatible with another person's behavioural tendency, or when a party wants some resources desired by others which are scarce in supply and as a result other peoples want may not be met fulfilled. No community, group, country or institution is immune from conflict because it is generally agreed that conflict is common to human relationships and societies and it is the result of interaction among people, an unavoidable concurrent of choices, decisions and an expression of the basic fact of human interdependence (Adejuwon and Okewale, 2009). This view has been attested to by Olaleye and Arogundade (2013) when they defined conflict as a by-product of the interaction of people or groups with different expectations, interests, and background in the society. Therefore, if conflict is a by-product of interaction among people, In fact, Chukwuemeka et al, (2012) argued that conflict is not only central to life but a life without conflict is no life at all.

Nigeria presents a complexity of ethno-religious identities which are often responsible for the recurring violent conflicts in the country. To emphasize the interconnectedness of ethnic and religious identities and the fact that they are often mutually reinforcing, they are sometimes compounded as ethno-religious. Ethno-religious religious crises in Nigeria have historical, geographical and political origins. They evolved from the old regional structures of the Nigerian federation, where identities were shaped by leaders of the dominant ethnic groups Hausa/Fulani in the Northern region (predominately Muslim), Igbo in the Eastern region and Yoruba in the Western region - that exercised some form of hegemonic control over the regions.

As a result, ethno-religious identities were, and continue to be, used as reference points for the dominant ethnic groups. With the division of the country into six geo-political zones, ethno-religious identities seem to have taken roots in Nigeria. However, the emergence of the farmer-herders conflict in Nigeria has worsened the already existing phenomenon of ethno-religious conflicts in the country. Herding is an occupation dominated by the HausaFulani who incidentally are predominantly Muslims while farming is the occupation of a large majority of Christians in the middle belt (also known as north central - where Nasarawa and Benue states are located). The regular outbreak of farmer-herders conflict in the middle belt region has severely affected the peace and tranquility of various regions in Nigeria.

Within the past two decades, violent conflicts, terrorism and banditry have increased in Nigeria resulting in general upsurge in criminality and insecurity. The country has been plagued by attacks from Islamic State in West Africa and Boko Haram terrorists. Similarly, Nigeria has witnessed incessant attacks from bandits coupled with violence, killings and destructions associated with herders-farmers conflict. Reaffirming this view, Chiluwa and Chiluwa (2020) posited that as the Nigerian government and the African Union (AU) grapple with the ISWAP and Boko Haram's rebellion, violent conflicts between herders and agrarian communities in the central and southern regions of Nigeria have escalated to fearful outcomes that are as deadly as that of Boko Haram.

\subsection{Brief Overview of Herders-Farmers Relationship in Nigeria}

Historically, the relationship between herders and farmers in Nigeria had been symbiotic and quite peaceful. According to Bagu and Smith (2017), while farmers benefitted from dung fertilizers produced by cattle, the herders enjoyed grazing rights and profited from the available markets. Also, the farmers and herders profited in the 
exchange of grain for dairy and crop residue for manure. Chiluwa and Chiluwa (2020), noted that disputes over land and encroachment of cattle into farmlands that sometimes developed, were resolved by local leaders from existing traditional conflict mitigation and resolution mechanisms. Tracing the origin of herders migration, the International Crisis Group (ICG, 2017:3), reported stated that in the early $20^{\text {th }}$ century, some herders began migrating southward due to series of drought in the north. Also, security was considered better in the central and southern Nigeria, as well as better control of parasitic animal diseases (e.g. sleeping sickness). Herders also wanted to evade the much-heated cattle tax imposed by the British colonial administration in the northern region. The migrations to the south, as well as economic, political and environmental changes weakened the mutual understanding between the farmers and the herdsmen. For instance, the introduction and the use of fertilizers in the 1980s and 1990s subsequently reduced farmers' reliance on manure from grazing cattle as synthetic fertilizers proved very effective in the cultivation and production of improved cash crops. By the 21 st century, migratory herds of cattle were now viewed as a nuisance and problem rather than necessity (Bagu \& Smith, 2017).

Furthermore, the International Crisis Group (ICG) 2017 report identified other factors that drove the herders from the north. For instance, grazing reserves that were established by the northern regional government were lost to rapid population growth and the associated demand for farmland, and space for urbanization and infrastructure. These and other cumulative effects reduced the availability of designated grazing reserves, leaving herders with no choice than seek pasture elsewhere. Insecurity, rural banditry and cattle rustling also drove the herders to the south (ICG, 2017:4-5). According to the ICG report, cattle rustling became a growing and profitable business in several northern states, mainly in Kaduna, Kano, and Zamfara states. Egwu (2016), submitted that more than 64,750 cattle were stolen and at least 2,991 herders killed in states across the north-central zone in 2013. And from 2011 to 2015 , bandits, cattle rustlers and other criminals killed 1,135 people in Zamfara state alone, (Vanguard newspaper, 2017). It can therefore be argued that fear and violence not only drove the herders southward, but also forced them to arm themselves with weapons to defend themselves and their livestock. Those who own cattle such as politicians and members of security forces that hire herdsmen to manage the cattle also began to arm these hired herders. Hence, criminal elements interacted with political, ethnic and religious tensions to exacerbate instability and deepen social divides (Chiluwa \& Chiluwa, 2020).

\subsection{Early Warning Mechanisms}

Throughout history, human beings have sought to warn and be warned of future calamities. From shrill-voiced soothsayers to cold war military strategists, the objective has always been to accurately predict impending dangers, usually in order to avoid them or, at least, to be better prepared for them (Dorn, 2013, cited in Nwaneri \& Uwakwe, 2017). In contemporary conflict prevention and management strategies, early warning mechanism and response has been introduced as an instrument. Indeed, it is gradually becoming a prerequisite for conflict preventive and management actions. Where prevention fails, early warning serves a later purpose. By being aware of the nature and antecedents of an escalation of violence, conflict management practitioners can consciously plan, if not to stop it, then to mitigate its effects and to shorten its duration. Early warning refers to "the communication of information on a crisis area, analysis of that information and the development of a potential, timely, strategic response options to the crisis" (Adelman, 1998). According to Haye (2014), early warning is basically concerned with prevention, mitigation or management of violent conflicts within a geographical landscape. Haye went on to distinguish between early warning system and intelligence system. He argued that early warning is not concerned with a direct threat to the gatherer or analyzer of the information, or those contemplating a response. According to Onuoha et al (2006), Early Warning is a process of reading specific indicators as signals and patterns of signals, and translating those patterns into kind of anticipation of the likelihood of the emergence or escalation of violent conflict. It entails the trends, sparks and triggers of conflict that can provide data for forecasting the emergence of conflict. Providing further insight on the definition of early warning, Matveeva (2006) posited that early warning include three elements, namely: knowledge and hazard mapping, monitoring and forecasting impending events, processing and dissemination of understandable warnings to political authorities, security agencies and other relevant stakeholders, as well as adoption of appropriate and timely action in response to such alerts.

Kumar Rupesinghe identifies ‘three generations' of early warning systems: The first generation early warning systems were the systems where the entire early warning mechanism (including conflict monitoring) was based outside the conflict region. The second generation amended this approach by basing the monitoring mechanism in the conflict zones, namely by having the field monitors to gather primary event data. The analysis, however, continued to be conducted outside the conflict region. The third generation early warning systems are entirely located in the conflict regions. They integrate early warning and early response together as simultaneous processes (Kumar, 2005). There are a variety of theoretical and practical approaches to early warning and response. Austin Alexander noted that in order to identify the causes of conflict, predict the outbreak of violence and mitigate the conflict, an early warning system should contain six core mechanisms: data collection, data analysis, assessment for warning or identification of different scenarios, formulation of action proposals, transmission of recommendations and assessment of early response (Alexander, 2003). Similarly, Nwaneri and Uwakwe (2017) 
identified the component of early warning including collection of information using specific indicators, analysis of information: attaching meaning to indicators, setting it into context, recognizing crisis development, formulation of best and worst case scenarios and response options and communication to decision makers.

\subsubsection{The Relevance of Early Warning System in Conflict Mitigation and Prevention in Nigeria}

According the European Centre for Conflict Prevention (2006), early warning and early response is considered one of the pillars of operational conflict prevention. Practiced by international organizations, research institutes and NGOs, early warning and response mechanisms has advanced the knowledge of conflicts and strengthened strategies to address them. Yet, its prospects and potentials have not been maximally utilized. The ultimate goal of early warning is not just to predict conflicts, but rather to prevent them or to facilitate their prevention by others. Therefore, reliable and effective early warning mechanisms provides not only time to prepare for short term containment but also to design, build support for and implement longer term proactive strategies and development program that can reduce the likelihood of future negative conflicts. Ayokunle et al (2004) observed that an early warning mechanism is more than the flow of information and reports from those on the ground regarding highly visible or rapidly escalating crises. It should also provide reliable analyses that identify still latent or low level conflicts or instabilities, while there is still time for investing in appropriate structural development and building conflict management capacity.

In the field of peace and conflict management, early warning systems are systems that collect, verify and analyze data in a systematic manner and on an on-going basis to provide information for a wide range of preventative purposes. These systems also provide recommendations for action by key decision-makers while providing an assessment of the impact of the situation (Enang, 2011). Early Warning Systems become successful when the information provided is useful in preventing, mitigating and resolving conflicts. Indicators help early warning actors to understand the nature of the impending conflict, ascertain the expected impact and determine a sufficient response. However, Stanton (2009) pointed out that in the case of the Rwandan genocide, there was no "Systematic understanding of how the genocide developed therefore warning signs could not be noticed". He added that "policy-makers did not understand the genocidal process, and so they missed the early warning signs". Indicators are therefore important in understanding the various contexts and situations that might arise.

Early Warning systems are a veritable mechanism for mitigating the impact of conflict as well as in the prevention of conflict. In the case of the herders and farmers conflict in Benue and Nasarawa states, such a mechanism should help government and other response agencies anticipate the likely outbreak of violence and take appropriate measures to defuse tension or prepare for managing the fall out of such violence. In attempting to deploy early warning in mitigating herders-farmers conflict in Nigeria at large and Benue and Nasarawa states in particular, community context sensitive early warning mechanisms needs to be development and utilized by government and other relevant stakeholders. Towards this end, first, early warning mechanisms must be defined. In line with this, early warner must sufficiently be well informed and knowledgeable about the trends and dynamics of conflicts in their domain. Second, these mechanisms must be closely observed and monitored. Third, warnings should not only be issued but must be seen to be communicated and where necessary sanctions imposed. Therefore, for early warning mechanisms aimed at herders-farmers conflicts in Benue and Nasarawa states to be effective, it must be followed up with deployment of early response instruments/approaches.

\subsection{Theoretical Framework}

\section{Eco-Violence Theory}

The subject matter under examination can be explained through the theoretical perspective known as "eco-violence theory". The eco-violence theory seeks to explicate the relationship between environmental factors and violent conflicts. Pioneered by Homa-Dixon (1999), the theory holds that:

Decreased in quality and quantity of resources, population growth, and resource access act singly or in various combinations to increase the scarcity, for certain population groups, of cropland, water, forests, and fish. This can reduce economic productivity, both for the local groups experiencing the scarcity and for the larger regional and national economies. The affected people may migrate or be expelled to new lands. Migrating groups often trigger conflicts when they move to new areas, while decreases in wealth can cause deprivation conflicts (Homer-Dixon, 1999:30, cited in Okolie, 2015).

Implicit in the eco-violence theory is the assumption that struggles over scarce ecological space and resources engender livelihood crisis, which, in turn, drives violent conflicts (Okoli and Atelhe, 2014:79). This situation derives impetus from the dynamics of climate change which have accentuated ecological scarcities and struggles across the world (Blench \& Dendo, 2005; Onuoha, 2007). The conflicts between the herders and farmers in Benue and Nasarawa states, north-central, Nigeria typify ecological resource-conflict aggravated by the impacts of global climate change. The issue in the conflicts is the livelihood struggles in a context of stiff ecological scarcity and competition. The desperation exhibited by the principal actors (herders and farmers) in the conflicts can only be 
properly conjectured by understanding the conflict situation as a struggle for collective subsistence in an ecological domain fraught with resource- scarcity and do-or-die contestation. In this context, it becomes expedient for the parties to apply counter-group tactics in an attempt to live through the ecological struggle. This apparently explains the level of violence that has characterized the herders-farmers conflicts situation in contemporary times.

\subsection{Discussion of findings \\ Contemporary Factors that have Sustained the Herders-Farmers Conflicts in Benue and Nassarawa States, Nigeria}

1.6.1. Climate Change

Globally, attention has been drawn to the negative effects of human activities on the environment. Over the years, industrial activities have had damaging consequences on the ecosystem resulting in climate change that has negatively impacted the environment. Findings from the study revealed that factors such as struggle over land ownership and usage, unclear boundary issues, ethnicity, among others constitute the remote causes of the herdersfarmers conflict in Benue and Nasarawa states, Nigeria. However, new dynamics have emerged that has continued to sustain the conflict in contemporary time and prominent among these is climate change. The study's respondents noted that there has been increased southward migration of herders due to the 'drying up' of the Lake Chad area as a result of climate change. The Lake Chad region is the major source of water for herders and their cattle. Therefore, herders are forced to migrate southward in search of water and green pastures for their herds. During the course of migration, herders often come in contact with crops planted by farmers. In many cases, due to poor monitoring of herds, the cattle often stray into farms thereby eating up crops and damaging farmlands. The resultant consequence is conflict (disagreement) between the herders and farmers which in most instances become violent. 1.6.2 Demographic Changes

Another contemporary factor identified by the study's respondents is the issue of demographic changes that have occurred in the study area (Benue and Nasarawa states). According to respondents, grazing routes established by the federal government have been converted for other reasons due to increased demand for land for farming and developmental purposes. Benue and Nasarawa states have witnessed increase in population growth and this in turn has led to increased demand for land by farmers. Therefore, the quest for land has led farmers into trespassing and converting grazing routes to farmlands. Similarly, instances abound where the two state governments acquired grazing routes and constructed public developmental project/utilities on them. Findings revealed that herders prefer moving within the grazing routes (where such exist) irrespective of whether crops are planted therein or not. This is because that is their 'official' movement route. On the other hand, farmers argue that land belongs to the community and families hence, the federal government does not possess the power to unilaterally deprive them of farmlands on the ground of establishing grazing routes for herders. This scenario is one of the intricate factors that have continued to sustain the herders-farmers conflict in Benue and Nasarawa states, Nigeria.

1.6.3 Increased grievances due to breakdown in intergroup relations

The inability of the conflicting parties (herders and farmers) as well as the failure of other stakeholders to effectively manage the conflict has led to entrenched anger and bitterness thereby resulting in breakdown of intergroup relations. Findings indicated that in the past, herders and farmers shared a good working relationship and assisted each other. Farmers used the wastes of cattle in fertilizing their crops. They also provided areas (such as uncultivated lands, harvested areas/farmlands) for herders to graze their cattle. The relationship was so harmonious that farmers provided shelter for herders if the need arises. Similarly, herders provide milk from their cattle to farmers as a sign of goodwill. However, years of violent confrontations between them have blunted the cordial relationship that existed between the two parties.

1.6.4 Ready availability of arms and influx of foreign herders

Conflicts and violence in the Sahel region has led to easy availability of small arms and light weapons. The activities of terrorist groups such as Boko Haram, Islamic State in West Africa, among others have made arms to fall into the hands of criminally minded foreign herders who use these arms to unleash mayhem on farmers. The porous nature of Nigerian borders makes it easy for these foreign elements to infiltrate the country and cause conflict. Respondents noted that the federal government has on various occasion stated that the herders killing and destroying agrarian communities in Benue and Plateau states are not from Nigeria. Findings revealed that Nigerian herders are not known to carry guns; rather, they are easily identified by the 'stick' they use in guiding and directing their cattle.

1.6.5 Weak institutional management frameworks

Respondents noted that governments at the federal and state levels have not shown sufficient determination and commitment towards ending the herders-farmers conflicts in Benue and Nasarawa states. Respondents described this situation as "lack of political will by government". According to respondents, various Judicial Commissions of Inquiry established by governments at the state and federal level have submitted White Papers where recommendations on how best to manage the conflict were made. However, government has consistently failed to implement these recommendations. Those found culpable have not been prosecuted by relevant authorities. As a 
result of this, the communities have resorted to self-help and this has led to the emergence of various militia groups in the two states. In consequence, a culture of impunity seems to have evolved with individuals and communities taking laws into their hands.

\subsection{Effects of the Herders-Farmers Conflicts on Benue and Nasarawa States, Nigeria}

1.7.1 Proliferation of ethnic militia/vigilante groups in the affected communities

The prolonged and intractable nature of the herders-farmers conflicts in Benue and Nasarawa states, Nigeria has led to the emergence of ethnic-based militia groups within the communities that are affected by the conflict. Findings revealed that many youths in these communities have grouped themselves together into various vigilante teams with the aim of safeguarding their communities. This is in response to the delay in arrival by security agents to communities during attacks by these foreign herders. Suffice to note that many of these communities are located in the interior of the states. Access roads and poor network communication makes it difficult for security operatives to respond speedily. Thus, these militia/vigilante groups hold sway in these communities.

1.7.2 Aggravated inter-communal tensions, suspicion and distrust

Respondents stated that years of conflict have made herders and farmers suspicious of each other. There is distrust on the part of both parties. The once harmonious relationship between herders and farmers in the two states has been overtaken by deep animosity with in turn fuels inter-ethnic, inter-communal tension, mutual suspicion and distrust by all parties. Findings revealed that this situation has significantly affected various conflict management efforts by stakeholders.

\subsubsection{Crippled the growth of the Nigerian agricultural sector}

Benue and Nasarawa states are major farming areas. Indeed, Benue state is known as "food basket of the Nation" due to the agrarian nature of the people and communities. The herders-farmers conflict has negatively impacted on the federal government's economic diversification policy as farmers have neglected their farms due to fear of attack. Respondents noted that many farming communities have been destroyed as a result of the herders-farmers conflict. Similarly, many young persons have abandoned farming and migrated to urban areas because of the destruction of their crops by cattle. All these have crippled the growth of the agricultural sector and worsened the state of unemployment in Nigeria.

\subsubsection{Upsurge in Internal Displacement of Persons (IDPs)}

Respondents pointed out that the herders-farmers conflict have made Benue and Nasarawa states occupy significant position in states with high number of internally displaced persons in Nigeria. According to respondents, in the north-central region of Nigeria, Benue and Nasarawa states accounts for the bulk of internally displaced persons. Majority of those in the IDP camps are individuals who fled their communities due to the herders-farmers conflict. The respondents noted that many schools have been converted to emergency IDP camps in order to provide shelter for displaced persons. This in turn has affected the academic pursuits of children of IDPs as well as students of schools being used as IDP camps. Findings revealed that students/pupils of such schools are transferred to other schools within the vicinity.

\subsubsection{Increased spending on security rather than development}

Respondents noted that the two state governments spend a large chunk of their resources on security. Funds that ought to have been used for developmental purposes are channeled into the provision of security. This is so because no meaningful development can take place in an environment ravaged by conflict. The implication is that developmental projects and infrastructures are not accorded the needed priority. Also, funds that are supposed to be used for new projects are used to rebuild those destroyed during violent conflicts between herders and farmers.

\subsection{How early warning mechanisms can be deployed and utilized towards mitigating the herders-farmers} conflicts in Benue and Nasarawa states, Nigeria

1.8.1 Establishment of early warning centers

Respondents harped on the need for government to establish early warning mechanisms at the state and community level in order to speedily track and identify early warning indicators at the community/grassroots level. This is in line with conventional approach to early warning which involves the preparation of internal, interpretative reports for policy makers, focusing on the substance of the assessment and the need to package the report to bring out available policy options. These are, typically based on field monitoring and community/grassroots situation studies, as argued by Nwaneri and Uwakwe (2017, Ayokunle, et al, 2004, Alexander, 2003). The respondents further noted that where such mechanism already exist, it should be strengthened for effective performance. Suffice to note that the Institute for Peace and Conflict Resolution (IPCR) which is the pioneer federal government agency with mandate for managing of conflict in Nigeria has an early warning office in Benue state.

1.8.2 Development of context specific early warning models

Every conflict has its own dynamics and context. Therefore, in order to develop an early warning mechanism that will address the herders-farmers conflicts in Benue and Nasarawa states, the mechanism needs to incorporate and integrate the peculiarities and context of the conflict. This will aid in developing a model that will ensure that the 
early warning indictors are generated and presented in an analytical format that fits into the dynamics of the conflict. Barakit refers to model as 'complementary approach' which he described as the generation of analytical reports employing explicit structural or dynamic models of crisis phenomena. He further stated that the model provide an essential complement to field monitoring and indicator monitoring through specifying the combinations of risk factors and sequence of events that are likely to lead to different types of crises distinguishing between remote and proximate conditions (Barakit, 2010).

\subsubsection{Identify and utilize existing data on the conflict}

Existing literature on the herders-farmers conflict such as book, journal articles, report of Commissions of Inquiry, Government White Papers, among others can provide the needed framework for deploying early warning mechanisms in managing the herders-farmers conflicts in Benue and Nasarawa states, Nigeria. Bloomfield and Moulton (1997) posited that this can provide rich information source that can be found in episodic data bases which profile past conflicts and crises, including information on crisis development and the effectiveness of attempts at crisis prevention or management. This can provide an empirical basis for recommending early response options to relevant stakeholders.

\subsubsection{Deploying early response mechanism}

Early warning mechanism in conflict management becomes ineffective where there is no corresponding early response mechanism to address the early indicators to conflict outbreak. Findings revealed that the herders and farmers conflict is cyclic i.e it is a periodic conflict. This implies that the conflict occurs at a particular period of time. This means that there is discernable pattern to the conflict that can be the basis for preventive measures. The conflict is cyclical in nature involving interchangeable periods of lull and escalation determined by seasonal variations/climatic changes. In other words, each escalation is accompanied by a period of retreat by the parties mostly as a result of the intervention of security agencies. When security agents are withdrawn on the understanding that peace has been restored, a new cycle starts usually at the onset of the dry season which is the period of southward migration of herders. Accordingly, this can sufficiently serve as early warning sign. Hence, early response mechanisms such as deployment of security agents into the conflict prone communities can be activated.

\subsection{Conclusion}

The loss of lives, destruction of property and internal displacement of persons associated with the farmers-herders conflict provides justification for the need to interrogate and identify workable strategies for its management. This study examined conflict mitigating capacities of early warning in the management of the seemingly intractable farmers-herders conflict in Nigeria using the north-central states of Nasarawa and Benue states as case study. The study's findings revealed that early warning has the prospect and potential to mitigate herders-farmers conflict in Benue and Nasarawa states. The activation and deployment of early warning mechanisms in the two states can build support and implementation of longer term proactive strategies and development programs that can reduce the likelihood of future occurrence of violent conflicts between herders and farmers in both states. It can also provide reliable information that can help prevent instability and conflict in the two states. Also, early warning mechanisms can generate information that may aid in identifying other factors driving conflict and insecurity in the two states. Lastly, it can serve as basis for assessing likely future scenarios and recommend appropriate options for intervention.

\section{Recommendations}

The study recommends that the government at the states and federal levels should determinedly implement feasible recommendations in the report of various Commissions of Inquiry on the conflict. Also, border security agencies needs effectively monitor Nigeria's borders to regulate the influx of foreign herders. Finally, the National Assembly need to make legislations on grazing that will incorporate, integrate and protect the interest of herders and farmers.

\section{References}

Abdulbaqi \& Ariemu (2017) "Newspapers framing of herdsmen-farmers' conflicts in Nigeria and its implication on peace-oriented journalism." The Creative Artists 11(2), 78-105.

Adejuwon, K. D. and Okewale, R. A. (2009). "Ethnic militancy, insurrections and democracy in Africa: The case of Nigeria", Journal of Social and Policy Issues, Vol. 6, No. 4.

Adelman, H. (1998). Difficulties in early warning: Networking and conflict management. In Kvan Walraven (Ed.). Early warning and conflict prevention, limitations and possibilities. The Hague: Kluwer Law International.

Akomolafe, C. O. (2001). The principal behaviours and staff development in Ekiti State Secondary Schools. Unpublished Ph.D. Thesis, Department of Educational Foundation and Management, Faculty of Education, University of Ibadan, Ibadan.

Alexander A, (2003) 'Early Warning and the Field: a Cargo Cult Science?', Berghof Handbook for Conflict 
Transformation, (Berghof Research Center for Constructive Conflict Management, Berlin: 2003).

Amao, O, Uzodike, N. O, Ettang, D, Tugizimana, C. (2014) revisiting the utility of the early warning and early response mechanism in Africa: Any role for civil society?. Peace and Conflict Review Journal, vol 8, no 1,

Anioke, U. (2002). Local government and conflict. Journal of Policy and Development Studies.Vol 3. No. 2.

Ayokunle F; Chuwkwuemeka E, \& Ifeanyi, O. (2004). "Conflict Monitoring in Nigeria: Developing Civil Society Action for Early Warning and Early Response”.'In Derrick M and Joseph S. (2004). (Eds), Fundamentals of Peace Practice in Nigeria: A Tool Kit. Book 1- Tracking Conflicts. IDASA.

Bagu, C. \& Smith, K. (2017) “Criminality \& reprisal attacks in Nigeria's Middle Belt." Search for Common Grounds: Available at: https://www.sfcg.org/wpcontent/ uploads/2017/04/Criminality-ReprisalAttack_FINAL.pdf

Blench, R. and Dendo, M (2005). Natural Resources conflicts in North-Central Nigeria. Department of International Development UK.

Bloisi, W. (2007). An Introduction to Human Resource Management, London: Mcgraw Hill Publishing Co.

Bloomfield, L. P. \& Moulton, A (1997). Managing International Conflict: From Theory to Policy. New York: St. Martin's Press.

Borisoff, D., and Victor, D. A (1998).Conflict management: A communication skills approach. Needham Height: Allynand Bacon, a Viacom Company.

Chiluwa, I, Chiluwa, I.M (2020), Deadlier than Boko Haram': Representations of the Nigerian herder-farmer conflict in the local and foreign press. Journal of Media, War \& Conflict (Sage)

Chukwuemeka, E. O., Ugwu, J., Okey, T., and Igwegbe, D. (2012). An empirical study of industrial conflict and management in Nigeria local government system: A study of Enugu State. International Journal of Human Resource Studies.Vol. 2 No. 3.

Domenici, K. and Littlejohn, S. W. (2001). Mediation: Empowerment in conflict management ( ${ }^{\text {nd }}$ ed). Long Grove. III. Waveland Press Inc.

Egwu, S. (2016) "The political economy of rural banditry in contemporary Nigeria." In M.J. Kuna \& Jibril Ibrahim (eds.), Rural Banditry and Conflicts in Northern Nigeria. Abuja: Centre for Democracy and Development, pp.14-68

Ejiogun, A. M. (1990). Educational management, a system approach. Lagos; Lartern Books

Ettang, D. (2011). Early Warning and Early Response Mechanisms in Africa; Gaps and Prospects. Consultancy Africa Intelligence's conflict and terrorism Unit.(conflict.terrorism@consultancyafrica.com) accessed on

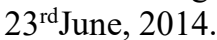

European Centre for Conflict Prevention (2006) Early Warning and Response: Conceptual and Empirical Dilemmas /International Secretariat of the Global Partnership for the Prevention of Armed Conflict.

Fatile, J. O. and Adejuwon, K. D. (2011). Conflict and Conflict Management in Tertiary Institution: the case of Nigerian universities. European Journal of Humanities and Social Sciences, Vol. 7 (1) 276.

Haye, J. (2014). A strategic peace building partnership: From early warning by civil society to early warning response by European Union. Retrieved from http://eeas.europa.eu/ifs/publications/articles/book2/book\%20vol2_part2_chapter16_a\%2Igu, S.

Henry, O. (2009). Organisational conflict and its effects on organizational performance, .Research Journal of Business Management.Vol. 2. No. 1, pp. 16-24.

Hocker, J. L., and Wilmot, W. W. (1985). Interpersonal conflict. Dubuque, lowa. Brown Publishers.

Homa-Dixon (1999) cited in Okolie, C. A (2015) Pastoral Transhumance and the Dynamics of Social Conflicts in Nasarawa State, North-Central Nigeria. In (ed) Kuna,M.J \& Ibrahim,J. Rural Banditry and Conflicts in Northern Nigeria.

Ilo, U.J., Jonathan-Ichaver \& Adamolekun, Y. (2019) “The deadliest conflict you've never heardof: Nigeria's cattle herders and farmers wage a resource war." Foreign Affairs (January 13). https://www.foreignaffairs.com/articles/nigeria/2019-01-23/

International Crisis Group (ICG, 2017): "Herders against farmers: Nigeria's expanding deadly conflicts",p.1. https://ec.europa.eu/knowledge4policy/publication/herders-against-farmers

Kumar R, (2005) 'A New Generation of Conflict Prevention: Early Warning, Early Action and Human Security', paper presented at the Global Conference on the 'Role of Civil Society in the Prevention of Armed Conflict and Peacebuilding', New York, July 2005.

Matveeva, A. (2006). Early warning and early response: conceptual and empirical dilemmas. The Netherlands: European Centre for Conflict Prevention/International Secretariat of the Global Partnership for the Prevention of Armed conflict.

Nahavandi, A., Denhardt, R. B., Denhardt, J. V., and Aristigueta, M. P. (2015). Organizational behavior. Sage Publication, Inc. California, USA.

Nwaneri, M, Uwakwe, I.S (2017). Harnessing Early Warning Systems as Instrument for Prevention of PostElection Violence in Nigeria. Journal of African Foreign Affairs (JoAFA) Volume 4, Numbers 1 \& 2, 
June/December 2017 pp 129-14

Okoli, A.C. and Atelhe G. (2004). Nomads against natives: A political ecology of herders/farmers conflicts in Nasarawa State, Nigeria. American International Journal of Contemporary Research, 4 (2) pp. 76 -88.

Olaleye, F. O. and Arogundade, B. B. (2013). Conflict management strategies of university administrators in South-West Nigeria. Kuwait Chapter of Arabian Journal of Business and Management Review Vol. 2, No.6; 96.

Onuoha, A, et al (2006) Training Manual on Community Conflict Monitoring and Early Warning. A document of International Foundation for Education and Self Help (IFESH) and Conflict Abasement through Local Mitigation (CALM), 2016.

Onuoha, F.C. (2007). The state and water conflict in Africa: A focus on the Lake Chad, 1960 - 2007. M.Sc. Thesis submitted to Department of Political Science, University of Nigeria, Nsukka Rahim, M. A. (2002). Towards a theory of managing organisational conflict.The international Journal of Conflict Management. Vol. 13, No. 3. Sahara Reporters http://saharareporters.com/2019/01/02/herders-murder-14- raze-houses plateau $\%$ E2\%80\%8B

Stanton, G. H. (2009). The Rwandan Genocide: Why Early Warning Failed. Journal of African Studies and Peace Conflicts, i(2), 6-25.

Suppiah, W., and Rose, R. (2006).A competence-based view to conflict management. American Journal of Applied Science 3 (7) 1905-1909. Vanguard, February 16, 2017

Yorid, A. Z. and Pakiza, H. S. (2013). An exploratory study into the causes of conflict and the effect of conflict management style on outcome in a competitive workplace. Journal of Managerial Sciences. Vol. 7 No. 2. 